\title{
O.М. Беш
}

\section{АНАЛІЗ РЕЗУЛЬТАТІВ КОМПЛЕКСНОГО МОНІТОРУВАННЯ ЕФЕКТИВНОСТІ ЛІКУВАННЯ БРОНХІАЛЬНОЇ АСТМИ}

Львівський національний медичний університет імені Данила Галицького

\begin{abstract}
Резюме. У статті представлений аналіз результатів комплексного моніторування ефективності лікування бронхіальної астми. Запропонований підхід до моніторування ефективності лікування пацієнтів, хворих на бронхіальну астму, дозволив проводити комплексну об'єктивну оцінку стану пацієнта, стратифікувати ризики і корегувати базисну терапію. Проведені дослідження показали, що через 12 місяців показники спірометрії, контрольованості астми, прихильності пацієнтів до лікування та якості життя зросли в обох групах, а також
\end{abstract}

Вступ. Бронхіальна астма (БА) відноситься до числа найбільш розповсюджених хронічних захворювань органів дихання. Протягом останніх років майже щороку пропонуються нові узгоджувальні документи, протокольні стандарти терапії даної патології, однак вирішити всі складності у практичному лікуванні і досягненні контролю над хворобою і сьогодні не вдається $[2,3,7]$. Результати багатьох іноземних і вітчизняних досліджень пояснюють таку ситуацію тим, що в переважної більшості пацієнтів не були використані всі існуючі можливості лікування і моніторування перебігу БА $[4,7]$. Зокрема, це стосується обмеженого застосування алерген-специфічної імунотерапії (АCIT) та вузького діапазону критеріїв оцінки ефективності лікування. Сьогодні доведено, що виключно медикаментозне лікування, яке діє на окремі ланки патогенезу БА, не запобігає прогресуванню алергічного захворювання і після закінчення вживання ліків симптоми алергії знову поновлюються [3]. Водночас на сьогоднішній день існують переконливі дані про те, що ефективність лікування БА значною мірою залежить від поінформованості пацієнта про свою хворобу, його прихильності до лікування та рівня співпраці між лікарем і хворим $[4,7]$. Проведені протягом останніх років дослідження показали, що значна частина пацієнтів, хворих на БА, ставляться 3 недовірою до потреби тривалого лікування і в результаті не дотримуються призначеного режиму терапії [7]. Викладена вище ситуація диктує потребу організації довготривалого моніторування хвороби.

Мета дослідження. Підвищити ефективність лікування бронхіальної астми шляхом вдосконалення спостереження за перебігом хвороби і лікуванням на підставі опрацювання додаткових критеріїв оцінки ефективності терапії та проведення заходів, що сприяють підвищенню прихильності хворих до лікування.

Матеріал і методи. Клінічні дослідження проводилися на базі I Міської клінічної лікарні ім. Князя Лева та поліклінічного відділення знизилося тригерне навантаження (за рахунок зменшення куріння, корекції супутньої патології та контролю екофакторів помешкання). Водночас кращі результати (достовірно вищі показники контрольованості бронхіальної астми, зменшення об'єму базисного лікування) показала група хворих, які отримували алергенспецифічну імунотерапію.

Ключові слова: бронхіальна астма, алергенспецифічна імунотерапія, комплексне моніторування ефективності лікування.

Львівської обласної клінічної лікарні. Обстежено 104 пацієнти віком від 18 до 50 років, які хворіли на БА. Критеріями включення у дослідження були: інтермітуюча чи персистувальна БА легкого та середньотяжкого перебігу (відповідно БА І, БА II, БА ІІІ), наявність загальних показань до ACIT побутовими алергенами, тривалість анамнезу БА не менше одного року та відсутність попередніх курсів АСІТ. Для проведення дослідження сформовано дві групи, які були ідентичні за віком, статтю, тяжкістю захворювання, однаковими вихідними показниками спірометрії та астма-контроль тесту. В основну групу увійшов 51 пацієнт, який поєднував базисне медикаментозне лікування (інгаляційні глюкокортикостероїди (ІГКС) або комбінацію ІГКС та $\beta_{2}$ агоністів пролонгованої дії або антилейкотриєнових препаратів) та АCIT. АСІT отримували 38 пацієнтів цієї групи із застосуванням ін'єкційних алергенів, 13 - отримували сублінгвальну ACIT. У групу порівняння увійшли 53 пацієнти, які відмовилися від проведення АСІТ і отримували лише базисну фармакотерапію. Усі пацієнти дали письмову згоду на участь у дослідженні. Специфічне алерготестування проводили за допомогою скарифікаційних та прик-тестів із набором стандартних побутових алергенів (суміш побутових алергенів та/або кліщі домашнього пилу - Dermatophagoides pteronissinus i Dermatophagoides farinae) виробництва ООО «Імунолог» (Україна) та «Севафарма» (Словенія).

$\mathrm{У}$ роботі використаний комплексний спосіб моніторування ефективності лікування пацієнтів із бронхіальною астмою, що включав оцінку контрольованості захворювання за допомогою Астма Контроль Тесту (Asthma Control Test), визначення показників зовнішнього дихання, дослідження якості життя пацієнтів, їх прихильності до лікування та моніторинг тригерних факторів. Для оцінки прихильності до лікування застосована власна анкета опитування, що включала сім запитань, які дозволяють отримати інформацію про прийом ліків пацієнтом, дотримання ним правил 
проведення інгаляційного лікування та виконання алерген-специфічної імунотерапії.

Спостереження за пацієнтами здійснювали протягом року шляхом проведення чотирьох планових візитів у клініку і здійснення двох телефонних контактів. На першому візиті усім пацієнтам проводили алерген-специфічне тестування, комп'ютерну спірометрію 3 тестом на зворотність бронхіальної обструкції 3 визначенням ОФВ1 та ПШВ, оцінювали якість життя за допомогою опитувальника Asthma Quality of Life Questionnaire (AQLQ) та контрольованість захворювання за допомогою Астма Контроль Тесту. Прихильність пацієнтів до лікування оцінювали за допомогою розробленої дослідниками анкети опитування. Також проводили визначення тригерних факторів (куріння, супутня патологія, несприятливі побутові і екологічні чинники). На другому-четвертому візиті (через 3, 6 і 12 місяців після початку лікування) оцінювали результати Астма Контроль Тесту, якість життя (AQLQ), прихильність пацієнтів до лікування та проводили комп'ютерну спірометрію і моніторинг тригерних факторів. Телефонні контакти здійснювали 3 метою контролю за дотриманням програми лікування через 1,5 місяця після першого і через три місяці після третього візиту.

На кожному візиті за потреби (залежно від результатів обстеження) проводили корекцію лікування.

Результати дослідження та їх обговорення. Середній вік пацієнтів в обох групах був приблизно однаковим і склав в основній групі $31,14 \pm 1,40$ (таблиця).

Для динамічної оцінки клінічних симптомів БА використовували п’ятитибальну шкалу, запропоновану в тесті контролю астми. Ступінь зміни нічної симптоматики оцінювався за кількістю нічних пробуджень (від одного бала - чотири нічних пробудження в тиждень або частіше) до п'яти балів у відсутність нічних пробуджень, спровокованих симптомами астми). Денні симптоми (свистяче дихання, задишка, кашель) оцінювали від одного бала (симптоми частіше ніж раз на день) до п’яти балів (відсутність симптомів).
Потребу в застосуванні $\beta_{2}$-агоністів швидкої дії оцінювали від одного бала (застосування три рази на день або частіше) до п'яти балів, коли потреби в застосуванні $\beta_{2}$-агоністів швидкої дії не було. За п'ятибальною шкалою оцінювали і фізичну активність. Особливо складним завданням для пацієнтів було оцінювання ступеня контролю хвороби в балах. Знаючи, що оцінка в п'ять балів характеризує повний контроль БА, вони намагалися саме так оцінити свою хворобу, оскільки вважали контролем постійне лікарське спостереження. Після підрахунку загальної кількості балів ми робили висновок про ступінь контрольованості захворювання. Оцінка в 25 балів означала повний контроль над астмою, 20-24 бали - трактувалася як частково контрольована астма, менше 20 балів - неконтрольована астма.

Проведені нами дослідження дозволили встановити, що при включенні в дослідження середні показники АКТ основної групи становили $15,42 \pm 0,42$, а групи порівняння - $15,34 \pm 0,28$. Через три місяці в основній групі загальний показник контрольованості зріс до 17,81 $\pm 0,26$, а в групі порівняння - до 17,24 $\pm 0,18$. Через шість місяців показники АКТ дорівнювали $18,22 \pm 0,09$ та $17,79 \pm 0,08$ відповідно. Зростання утримувалося і через дванадцять місяців $(21,35 \pm 0,36$ та $19,41 \pm 0,32$, відповідно $p<0,001)$. Найшвидше регресували нічні симптоми, їх контрольованість зросла протягом дослідження в основній групі 3 $3,10 \pm 0,08$ до $4,59 \pm 0,07$, у групі порівняння - 3 $3,06 \pm 0,07$ до 4,0 0,06 . Динаміка показників контрольованості БА протягом 12-місячного спостереження представлена на рисунку 1.

Динамічні зміни показників АКТ підтверджені результатами спірометричних досліджень. При включені в дослідження середні показники ОФВ1 в обох групах були приблизно однаковими. В основній групі середній показник ОФВ 1

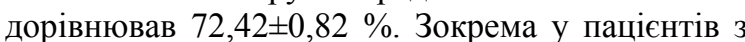
БА І він становив 77,82 $\pm 0,64 \%, 3$ БА II $74,43 \pm 0,81 \%$, 3 БА III - 68,34 $\pm 1,18$ \%. У групі порівняння середній вихідний показник ОФВ1 становив 72,64 $\pm 0,72 \%$ (БА І - 78, $17 \pm 1,27 \%$, з БА II $-74,09 \pm 0,77 \%$, БА III - 68,19 $\pm 0,85 \%$ ). Через

Таблиця

Розподіл пацієнтів за віком та статтю

\begin{tabular}{|c|c|c|c|c|}
\hline \multirow{2}{*}{$\begin{array}{c}\text { Тяжкість } \\
\text { бронхіальної астми }\end{array}$} & \multicolumn{4}{|c|}{$\begin{array}{c}\text { Середній вік } \\
32,14 \pm 1,32\end{array}$} \\
\cline { 2 - 5 } & $\begin{array}{c}\text { Основна група }(\mathrm{n}=51) \\
31,14 \pm 1,40\end{array}$ & \multicolumn{2}{c|}{$\begin{array}{c}\text { Група порівняння }(\mathrm{n}=53) \\
34,06 \pm 1,30\end{array}$} \\
\cline { 2 - 5 } & $\begin{array}{c}\text { Чоловіки }(\mathrm{n}=26) \\
28,62 \pm 1,41\end{array}$ & $\begin{array}{c}\text { Жінки }(\mathrm{n}=25) \\
33,76 \pm 1,91\end{array}$ & $\begin{array}{c}\text { Жінки }(\mathrm{n}=26) \\
38,92 \pm 1,59\end{array}$ \\
\hline Інтермітуюча БА I & $24,33 \pm 2,07$ & $34,60 \pm 2,11$ & $26,37 \pm 2,59$ & $37,80 \pm 2,92$ \\
\hline $\begin{array}{c}\text { Легка персистува- } \\
\text { льна БА II }\end{array}$ & $31,30 \pm 2,06$ & $29,43 \pm 3,51$ & $28,87 \pm 2,78$ & $36,70 \pm 3,45$ \\
\hline $\begin{array}{c}\text { Персистувальна } \\
\text { середньої тяжкості } \\
\text { - БА ІІІ }\end{array}$ & $28,50 \pm 2,57$ & $35,77 \pm 2,98$ & $31,91 \pm 2,86$ & $41,45 \pm 1,59$ \\
\hline
\end{tabular}


три місяці показники ОФВ1 покращились: в ос-

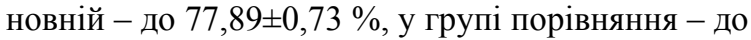
$78,08 \pm 0,69$ \%. Позитивна динаміка спостерігалася також через шість $(85,12 \pm 0,39$ і $81,92 \pm 0,44$ відповідно) та 12 місяців $(87,08 \pm 0,37$ і 83,34 $\pm 0,40$ відповідно).

Проведені спірометричні дослідження показали позитивні зміни в середніх значеннях ПШВ. На старті дослідження в основній групі вони склали $74,40 \pm 1,15$ (БА I - 83,25 $\pm 1,56$, БА II $78,34 \pm 1,23$, БА III - 67,26 $\pm 0,86)$, у групі порівняння - 75,42 $\pm 1,09$ (БА I - 83,51 $\pm 0,77$, БА II $78,78 \pm 1,30$, БА III - 67,9 $\pm 0,87)$. Динаміка показників ПШВ протягом 12-місячного спостереження представлена на рисунках 2 i 3.

Важливим критерієм ефективності лікування $\epsilon$ оцінка якості життя хворого, адже традиційні методи обстеження дають лише однобічне уявлення про хворобу і ефективність лікування, не дозволяючи оцінити психологічну, соціальну дезадаптацію та відношення пацієнта до захворювання. Протягом останніх десятиліть все більше уваги приділяється вивченню якості життя хворих людей. Важливо, щоб сама хвороба та оптимальні терапевтичні заходи не впливали на комфортність життя пацієнта та його сім’і. Сьогодні існує багато опитувальників, які дають можливість оцінити якість життя хворих. Вони мають різну чутливість і валідність. Для оцінки якості життя пацієнтів ми намагалися знайти опитувальник, який би був доступним для застосування саме в нашій групі хворих, стандартизованим (єдиний варіант стандартних відповідей і питань для всіх груп респондентів), чутливим до змін різних параметрів якості життя в кожного респондента, простим у користуванні та стислим. Саме таким вимогам відповідає опитувальник Asthma Quality of Life Questionnaire (AQLQ), адаптований для України українською і російською мовами $[5,6]$. Робота 3 опитувальником виявилася не простою. Правильність відповідей залежала від того, наскільки добре пацієнт розумів запитання. Саме тому перше застосування опитувальника вимагало певного часу, який відводився на навчання пацієнта. У кожному конкретному випадку ми оцінювали наскільки добре розуміє пацієнт запитання і наскільки правильно він на них відповідає. Більше того, у процесі опитування ми зіштовхнулися з тим, що пацієнти переважно не чекають того ефекту від лікування, якого сьогодні можна досягти. Вони не розуміли, що можна жити з БА, не відчуваючи іiї симптомів. Більшість пацієнтів у процесі опитування відзначали наявність значних симптомів БА (сухий нападоподібний кашель, свистяче дихання), і водночас вважали своє самопочуття абсолютно задовільним, а якість життя високою. Окрім цього, пацієнти весь час намагалися з'ясувати, які відповіді є правильними. Їм тяжко було зрозуміти, що неправильних відповідей на ці питання просто нема.

Якість життя, визначена за допомогою опитувальника AQLQ, дозволяє оцінити обмеження активності та емоційну сферу пацієнта, а також вираженість симптомів БА і відношення людини до свого захворювання. Відповіді на запитання опитувальника оцінювали за 7-бальною шкалою, причому один бал відповідав максимальним, а сім - мінімальним порушенням якості життя. На момент включення в дослідження показники обох груп були достовірно нижчими порівняно 3 розрахунковим максимумом у сім балів. Пацієнти відмічали обмеження активності $(3,57 \pm 0,05$

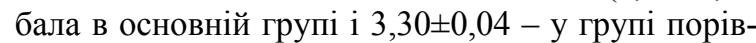
няння) та існування виражених симптомів БА

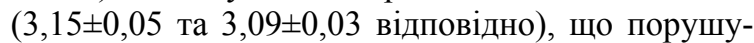
вало емоційну рівновагу $(3,71 \pm 0,06$ та $3,60 \pm 0,04$ відповідно). Загальна оцінка якості життя складала у хворих основної групи 3,55 $\pm 0,05$ бала, а в

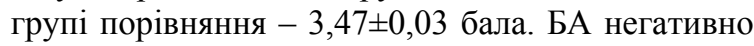
впливала на якість життя хворих, створюючи певні психологічні, емоційні і фінансові проблеми. Хвороба обмежувала життєву активність пацієнтів і їх працездатність, призводила до соціальної дезадаптації та психологічного дискомфорту. Дана патологія вимагала значних обмежень у способі життя. Найсуттєвішими для пацієнтів обох груп були емоційні проблеми. Зокрема, найбільш актуальним було відчуття страху та тривоги перед небезпекою розвитку загострення хвороби. Потреба тривалого застосовування базисної терапії (ІГКС, $\beta_{2}$-агоністів пролонгованої дії, антилейкотриєнових препаратів) викликала в пацієнтів страх за можливі побічні ефекти та віддалені наслідки такого лікування.

Через три місяці від початку спостереження ситуація суттєво змінилася, фізична складова

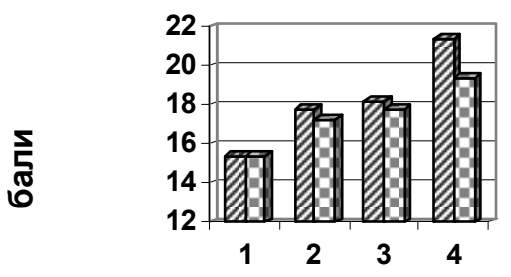

■ основна група

曰 група порівняння

\section{візити}

Рис. 1. Динаміка показників контрольованості хвороби протягом 12- місячного спостереження 


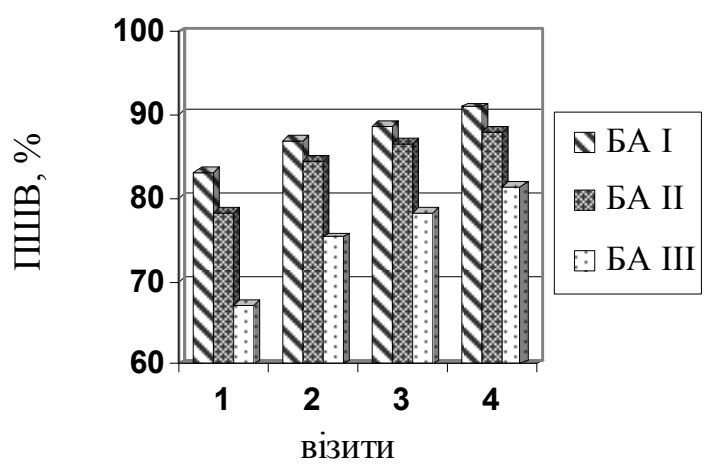

Рис. 2. Динаміка показників ПШЛ протягом 12 місяців в основній групі

якості життя стала суттєво кращою в обох групах, покращився і емоційний стан пацієнтів. Середній показник якості життя пацієнтів через три місяці після початку дослідження складав відпо-

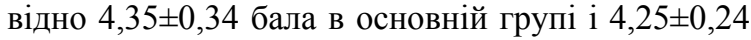
- у групі порівняння. Через шість місяців ці покаЗники дорівнювали $4,81 \pm 0,25$ та 4,64 $\pm 0,24$ відпо-

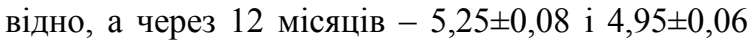
бала відповідно, $\mathrm{p}<0,001$.

Тривале спостереження (протягом одного року) дало можливість не лише здійснювати ефективний контроль за перебігом хвороби, але й за потребою коригувати тактику базисного лікування. Згідно з існуючими настановчими документами корекція лікування проводиться через кожних три-шість місяців [1]. У більшої частини пацієнтів основної групи [(35 (68,5 \%) пацієнтів] вдалося знизити фармакологічне навантаження (зменшити добові дози інгаляційних глюкокортикостероїдів та $\beta_{2}$-агоністів пролонгованої дії), тоді як у групі порівняння об'єм фармакотерапії частіше залишався незмінним або в окремих випадках [12 (22,6 \%)] розширювався. Таку ситуацію ми пояснюємо тим, що поєднане застосування АCIT та фармакотерапії не тільки контролює запалення, але й дозволяє виробити толерантність до конкретних алергенів за рахунок поступового збільшення дози алергену.

Використаний у роботі оптимізований комплексний спосіб моніторування передбачав динамічну оцінку прихильності пацієнтів до лікування. На початку дослідження середній показник прихильності пацієнтів до лікування був низьким i складав $3,25 \pm 0,32$ та $3,32 \pm 0,26$, відповідно в основній групі та групі порівняння. Для того, щоб якось змінити ситуацію на кожному візиті проводилися індивідуальні бесіди 3 пацієнтами щодо потреби тривалого лікування та дотримання лікарських рекомендацій, перевірялися правильність проведення АСІТ та інгаляцій препаратів базисної і симптоматичної терапії, а також проводився моніторинг тригерних факторів (куріння, супутня патологія, несприятливі побутові й екологічні чинники). Основна увага в таких бесідах відводилася тому, щоб пацієнти зрозуміли сутність БА, знали їі симптоми, розуміли їх серйозність та мінливість і вміли ними керувати. Обов'язково розпо-

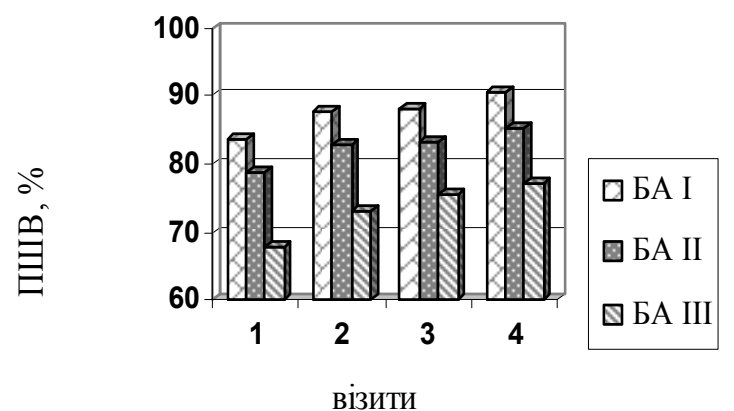

Рис. 3. Динаміка показників ПШВ протягом 12 місяців у групі порівняння

відали хворому також і про те, які побічні явища можуть виникнути під час лікування і як треба діяти в таких випадках. Окрім цього, ми виясняли який спосіб життя веде пацієнт і пояснювали потребу його модифікації (припинення тютюнокуріння, активний рух і виконання фізичних вправ, дотримання гіпоалергенної дієти тощо). Окрім вказаних вище заходів, пацієнти отримували лікування супутніх захворювань, зокрема артеріальної гіпертензії, гастроезофагального рефлюксу, полінозу, захворювань щитоподібної залози, ожиріння, цукрового діабету.

Проведені нами дослідження показали, що через три місяці в обох групах зросла прихильність пацієнтів до лікування (відповідно

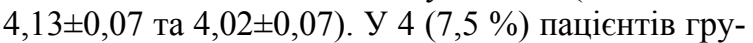
пи порівняння виявлені порушення режиму медикаментозного лікування і проведена заміна типу інгаляційного пристрою. Слід відзначити, що серед пацієнтів основної групи не зареєстровано жодного випадку самовільного порушення режиму АCIT. Зростання показників прихильності зберігалася в обох групах і через шість $(4,47 \pm 0,13$ та $4,18 \pm 0,25$ відповідно) та 12 місяців $(5,96 \pm 0,1$ та 5,57 $\pm 0,08$ відповідно, p=0,009) від початку спостереження.

\section{Висновки}

1. Запропонований підхід до моніторування ефективності лікування пацієнтів, хворих на бронхіальну астму, дозволяє проводити комплексну об'єктивну оцінку стану пацієнта, стратифікувати ризики і корегувати базисну терапію.

2. Традиційні методи обстеження із залученням фізикальних та інструментальних досліджень дають можливість неповністю оцінити стан пацієнта, оскільки не дозволяють отримати інформацію щодо його психологічної та соціальної адаптації до хвороби та прихильності до лікування.

3. Проведені дослідження дозволяють стверджувати, що через 12 місяців показники спірометрії, контрольованості астми, прихильності пацієнтів до лікування та якості життя зросли в обох групах, а також знизилося тригерне навантаження (за рахунок зменшення тютюнокуріння, корекції супутньої патології та контролю екофакторів 
помешкання). Водночас кращі результати (достовірно вищі показники контрольованості бронхіальної астми, зменшення об'єму базисного лікування) показала група хворих, які отримували алерген-специфічну імунотерапію.

Перспективи подальших досліджень полягають у розширенні застосування запропонованої комплексної системи моніторування, що сприятиме підвищенню контролю бронхіальної астми. Планується видавання методичних рекомендацій.

\section{Література}

1. Вишнивецкий И.И. Диагностика и выбор стартовой терапии бронхиальной астмы в рекомендациях GINA 2014: новые акценты и вопросы, оставшиеся без ответа / И.И. Вишнивецкий // Здоров'я України. - 2014. № 3. - С. 9-11.

2. Європейський вибір у лікуванні алергічних захворювань органів дихання / Б.М. Пухлик, С.В. Зайков,
І.В. Гогунська [та ін.] // Астма і алергія. - 2012. № 4. - C. 37-45.

3. Корицька I.В. Алерген-специфічна імунотерапія: сучасні рекомендації та практичні аспекти / І.В. Корицька, Д.О. Корицька / Клин. имунол. Аллергол. Инфектол. - 2009. - № 9. - С. 9-12.

4. Ласиця Т.С. Проблема прихильності до інгаляційної терапії у пацієнтів з ХОЗЛ / Т.С. Ласиця // Укр. пульмонол. ж. - 2012. - № 1. - С. 61-67.

5. Оценка качества жизни у пациентов с обострением бронхиальной астмы / Ш.З. Загидулин, Е.С. Галимова, О.А. Суховская [и др.] // Пульмонология. - 2013. № 1. - C. 49-53.

6. Asthma Control Test and Asthma Quality of Life Questionnaire Association in Adults / A.O. Alpaydin, M. Bora, A. Yorgancioglu [at al.] // Iran J. Allergy Asthma Immunol. - 2012. - №11. - P. 301-307

7. Adherence to inhaled therapies, health outcomes and costs in patients with asthma and COPD / M.J. Mäkelä, V. Backer, M. Hedegaard [at al.] // Respir. Med. - 2013. № 107. - P. 1481-90.

\section{АНАЛИЗ РЕЗУЛЬТАТОВ КОМПЛЕКСНОГО МОНИТОРИНГА ЭФФЕКТИВНОСТИ ЛЕЧЕНИЯ БРОНХИАЛЬНОЙ АСТМЫ}

\section{O.M. Беш}

Резюме. В статье представлен анализ результатов комплексного мониторинга эффективности лечения бронхиальной астмы. Предложенный метод мониторинга эффективности лечения больных бронхиальной астмой позволяет провести комплексную объективную оценку состояния пациента, стратифицировать группы риска и корректировать базисную терапию. Проведенный анализ показал, что исследуемые параметры (показатели спирометрии, параметры контролируемости астмы, приверженности пациентов к лечению и показатели качества жизни) выросли через 12 месяцев в обеих группах, также снизились тригерные нагрузки (за счет уменьшения курения, коррекции сопутствующей патологии и контроля экофакторов жилья). В то же время, лучшие результаты (достоверно более высокие показатели контролируемости бронхиальной астмы, уменьшение объема базисного лечения) показала группа больных, которые получали аллерген-специфическую иммунотерапию.

Ключевые слова: бронхиальная астма, аллерген-специфическая иммунотерапия, комплексный мониторинг эффективности лечения.

\section{ANALYSIS OF COMPLEX MONITORING OF ASTHMA TREATMENT EFFECTIVENESS}

\section{O.M. Besh}

Abstract. The results of the comprehensive monitoring of the effectiveness of treatment of bronchial asthma are presented in the article. The proposed approach to monitoring the effectiveness of treatment of patients with bronchial asthma enables the comprehensive objective assessment of the condition of the patient, to stratify risk groups and modify basic therapy. Studies have shown that indexes of spirometry, control of asthma, patients' adherence to treatment and quality of life increased in both groups after 12 months. The level of trigger load (smoking, comorbidity and cofactors apartments) decreased too. At the same time, a group of patients who had received allergen-specific immunotherapy obtained the best results (significantly higher level of control of asthma, decreased baseline treatment).

Key words: bronchial asthma, allergen-specific immunotherapy, comprehensive monitoring of the treatment effectiveness.

Danylo Halytskyi National Medical University (Lviv)

Рецензент - проф. О.К. Колоскова

Buk. Med. Herald. - 2015. - Vol. 19, № 1 (73). - P. 18-22

Надійшла до редакції 06.01.2015 року

(c) O.M. Беш, 2015 